\title{
The Current State of the Teaching the Russian Language in the Multicultural Russian School
}

\author{
Natalia I. Kytina ${ }^{1 @ \otimes}$, Elizaveta A. Khamraeva ${ }^{2,3}(\mathbb{D}$ \\ ${ }^{1}$ Domodedovo Secondary School No. 12, \\ 17 Kolkhoznaya St, Pavlovskoye, 142030 Russian Federation \\ ${ }^{2}$ Moscow State Pedagogical University, \\ 1 Malaya Pirogovskaya St, bldg 1, Moscow, 119991, Russian Federation \\ ${ }^{3}$ Herzen Russian State Pedagogical University, \\ 48 Naberezhnaya Reki Moiki, Saint Petersburg, 191186, Russian Federation
}

$\bigotimes$ kytinanatalia@mail.ru

\begin{abstract}
Although it is commonly known that the dominant trend in the development of modern post-industrial society is globalization, today we can already talk about 'glocalization' as a bidirectional process of integration and localization, complementary to the dialectical development of mankind. This process implies the unification of all spheres of social life in a single global space and the isolation of individual regions and ethnic groups as a protective reaction to preserve their uniqueness and identity. The described social trends are now becoming decisive for the development of the education system as the main social institution. Migration processes and related problems of integrating migrants into a new society, preserving the national language and culture, searching for identity - all these phenomena necessitate innovative methodological solutions that should be implemented in the context of learning the Russian language at a multicultural Russian school. The article considers topical problems related to the implementation of the program of teaching the Russian language in a multicultural environment. The authors propose a conceptual definition of a multicultural school. They analyze the pedagogical experience of individual educational institutions developing their own training methods for use in a multicultural environment. This analysis makes it possible to identify socio-adaptive, cultural, psychological and linguistic aspects of teaching Russian in a multicultural school. Along the way, an increase in the psychoemotional burden of teachers working in multi-ethnic classes is noted. Additionally, the effective experience of implementing preschool language training of non-native speakers in the Moscow region is analyzed. In line with the above, the authors review the current situation with regard to teaching the Russian language in the multiethnic regions of Russia through the example of the Republics of Sakha (Yakutia) and Tatarstan. In particular, it is noted that for the regions of the Russian Federation it is methodologically incorrect to use the term "multicultural school", since in the national constituent entities of the Russian Federation there is a special type of "national" school, and a program for studying Russian as a non-native language is also being implemented.
\end{abstract}

Key words: pedagogy, teaching the Russian language, multicultural school, multiculturalism, social adaptation, non-native speakers, language education, multiethnic environment

(C) Kytina N.I., Khamraeva E.A., 2021

(7) This work is licensed under a Creative Commons Attribution 4.0 International License https://creativecommons.org/licenses/by/4.0/ 


\section{Introduction}

The well-known thesis of M. Heidegger that "language is the house of being" (Heidegger, 2002) does not lose its relevance in modern society. In this regard, language learning is becoming an extremely significant issue not only for the development of communication skills and the acquisition of grammatical norms, but also as a factor of socialization, a necessary condition for revealing the inner potential of children and creating a safe cultural environment for them. The Russian Federation is a multicultural state. The total number of all the nationalities and ethnic groups in the Russian Federation is up to 190. In addition, Russia is an ethno-territorial federation, which determines various legal regimes for designing educational plans and strategies in national and territorial regions. In national regions, the use of two or more state languages is enshrined at the legislative level, which obliges schools to implement educational programs in accordance with the wishes of parents and the norms of the law. Migration flows, which have intensified in the last decade, also contribute to the formation of a multicultural Russian school, in which a significant percentage of students are children of new compatriots for whom Russian is not their native language. In this regard, the problems that arise when the Russian language is taught in a multicultural educational environment become extremely important, because the harmonious development of educational technologies within the framework of basic school education depends on their resolution. ${ }^{1}$

The issues of the socio-cultural adaptation of children in the educational process became the subject of academic research in the middle of the 20th century. Such attention to the problem was due to the migration situation in Europe: flows of refugees and migrants were forced to form a multicultural environment in mono-ethnic regions of Western Europe, actualizing the need to establish a mechanism for social adaptation and integration of migrant children into the educational space of the host country. The sociological interpretation of social adaptation was first substantiated in the works of M. Weber, R. Merton (Weber, 1990; Merton, 1968).

Currently, the issues of teaching children in multicultural classes are being intensely studied by scientists in the United States (Banks, 1993; Anderson, Stillman, 2013; Gay, 2010; Ladson-Billings, 2014), in Latin America (AntropGonzález et al., 2008; Darder, 2012) and Europe (Faas, 2011; Bunyan, 1991; Garreta Bochaca, 2006; Heckmann, 2008; Jackson et al., 2007) and others.

In Russian science, the problem of teaching the Russian language in a multicultural school is reflected in the works of researchers in pedagogy, sociology, cultural studies, philosophy and other related sciences. The general methodological concepts related to linguistic and cultural adaptation in the conditions of school education since the beginning of the 1980s have been developed by T.N. Yudina (2006), E.A. Khamraeva (2020), V.I. Mukomel (2014), G.D. Dmitriev (1999), Zh.T. Toshchenko (2015), T.M. Balykhina (2007), G.N. Chirsheva (2013), I.A. Pugachev (2011), S.A. Panarin (2015), N.M. Rumyantseva (2019), O.V. Sinyova

${ }^{1}$ Federal Law "On education in Russian Federation" of No 273-03 from December 29, 2012, with changes 2017-2016 year. (In Russ.) Retrieved September 20, 2021, from https://zakonob-obrazovanii.ru/3.html 
(2005), E.A. Pain (2020), E.V. Kakorina (2016), A.I. Ahiezer (2013), I.P. Lysakova (2009), R.F. Mukhametshina (2014). The problems of adaptation and integration of forced migrants into the school system in Central Russia and Moscow are studied by Yu.A. Goryacheva (2015), D.V. Poletaev (2019), Zh.A. Zayonchkovskaya (2019), O.N. Kalenkova (2012), S.K. Olimova (2019), E.Yu. Protasova (2010), N.M. Rodina (2010), T.A. Shorina (2012) and others. The most relevant practical studies of the 21st century include the works of E.A. Stolbova (2014), E.I. Sukhushina (2015), T.Yu. Usha (2012), E.P. Nikiforova (2016), L.P. Borisova (2012), S.N. Shadrina (2012) and others.

The purpose of present work is a multifactorial analysis of existing methods and practices of teaching the Russian language in a multicultural Russian school, systematization and structurization of the main studies devoted to the problems of teaching the Russian language in the multiethnic educational space of the Russian Federation. This analysis will make it possible to make a conclusion about the relevance and degree of methodological development of the problem, identify effective methods for resolving the discussed aspects related to the teaching methodology in multicultural classes, and also formulate possible practical recommendations in the field of the theory of intercultural communication and sociocultural adaptation.

\section{The subject matter of the study}

The work is carried out within the framework of the neoinstitutional methodological paradigm, which allows the authors to correlate formalized elements with the study of factors and phenomena that are not institutionalized within the framework of modern diagnostic capabilities. In this case, in addition to substantiating the need for a regulatory framework, our subject of research is the socialization of the individual, issues of cultural adaptation, development of tolerance and intercultural communication skills among children and adolescents.

The work is based on a systematic approach that allows us to consider all the studied variables in the context of a single educational system. The use of general methodological research methods (method of analysis and synthesis, idealization, abstraction) provide methodological integrity, validity of judgments and consistency of the narrative.

The study showed that, at present, a Russian school can be considered "multicultural", if more than $15-20 \%$ of its students are non-native speakers, that is, Russian is not their native language, and they do not have a level of knowledge of the Russian language that would allow them to completely master the school curriculum in Russian. Today, the growth in the number of multicultural schools in Russia is due to migration flows caused by the socio-economic and political crisis in the post-Soviet space. The joint training of native speakers and non-native speakers creates significant problems for the comprehensive study of the Russian language. For multicultural Russian classes, the educational and methodological complexes developed for learning Russian as a non-native language are not suitable (Rumyantseva, Rubtsova, 2019).

A debatable issue is also the statement of the need to introduce additional classes or language training courses for non-native speakers at school. In addition, when developing methods and tools for working in multiethnic classes, it is necessary to take into account the importance of preserving the language and culture 
of the children of new compatriots, which prevents the replacement of the matrix of the native language by the Russian language.

The study also provides a practical analysis of the pedagogical situations that have developed in relation to the study of the Russian language in the territories of the national republics of the Russian Federation. It can be concluded that ethnolinguistic situations are different in the regions. For example, the experience of teaching Russian as a non-native language to the indigenous small-numbered peoples of Yakutia can be considered effective and successful. At the same time, the program for learning the Russian language in secondary schools of the Republic of Tatarstan is at the center of discussions among specialists due to the discrepancy between the legislatively enshrined principles of designing education and the practical implementation of the program.

\section{Theoretical and methodological foundations of teaching non-native learners in a multicultural Russian school}

The problem of teaching the Russian language in a multicultural Russian school is not qualitatively new. The Russian school has been multiethnic in the broad sense of understanding this concept throughout the history of its institutional design and development. More than a hundred different nationalities and ethnic groups lived in the Russian Empire and on the territory of the USSR (Ahiezer, 2013). In a society where monolingualism formally prevails, there is almost always bilingualism (multilingualism) or at least diglossia (proficiency in various variants of the language), not to mention bi- or multiculturalism (proficiency in two or more cultures) (Markosyan, 2004). In the Soviet Union, in the territories of compact residence of ethnic groups and the predominance of the non-Russian population, the practice of teaching Russian as a non-native language was implemented. Although this technique showed its high efficiency, it cannot be applied in the conditions of the modern Russian multicultural school.

It should be noted that the methodology for teaching Russian as a non-native language can be successfully implemented if a number of conditions are met: for all children studying in the class, Russian is a non-native language. Therefore, teaching the Russian language is based on the principles of comparative studies, i.e., on identifying the similarities and differences in the target language and the native language, the teacher is a native speaker of a non-Russian language who has undergone special training and has the skills to implement the above comparison methodology in the process of learning the Russian language. Modern multicultural schools have completely different structural conditions. To identify the features of schools of this type, let us turn to the definition of the concept itself, which is given by domestic researchers and teachers.

The modern multiethnic school is "a new type of ordinary Russian school, in which non-Russian-speaking children without knowledge of the Russian language are taught not in separate classes, but together with Russian-speaking ones, entering not only the first, but also other, senior, grades without any special preliminary language training" (Sukhushina, 2015).

A "non-native speaker" is a person who not only speaks a different language but also has a corresponding worldview, which differs from that of the titular nation (Azimov, Shukin, 2009). To define the concept of a "speaker of another language" in the context of the educational space, one can use other interpretations, 
but the term "non-native speaker" seems to us the most relevant, easy-to-use and reflecting essential elements.

Thus, we can conclude that the program of teaching Russian as a non-native language is still being successfully implemented in the national republics of the Russian Federation in schools where Russian is non-native for all students, but this methodology is not suitable for modern multiethnic schools due to the structural features in the modern multicultural class, such as:

1) many ethnic groups with a total number of $15-25 \%$ (while representatives of 8-9 ethnic groups can study in one class);

2) the teacher is a native speaker of Russian and does not know how to teach Russian as a foreign language;

3 ) the entire academic and methodological complex, including textbooks, manuals, notebooks and other didactic materials, is aimed at native speakers of the Russian language (Stolbova, 2014).

Solving global problems of creating a single multicultural educational space based on intercultural dialogue, the methodologists are faced with the task of systematizing and structuring existing models of teaching the Russian language to representatives of different ethnic groups, taking into account their cultural, religious, educational universals, peculiarities of mentality, national character and stereotypes of behavior (Pugachev, 2011).

In a multicultural Russian school, the teacher faces a number of difficulties (Khamraeva, 2017). First of all, attention should be paid to the professional competence of a teacher when choosing an educational program and teaching aids for non-native speakers (Russian as a foreign language, Russian as a non-native language, Russian as a second language). The severity of the problem lies in the fact that the existing educational materials and teaching aids still do not have a national status: they are used as author's programs, accompanying courses to the discipline "Russian language" or are not represented in the Federal State Educational Standard. But the most urgent problem for a teacher working in a multiethnic class seems to be the ability to navigate in the experience gained over two decades of the post-Soviet period (2000-2021) of working with such children, building an individual working trajectory, taking into account the ethnolinguistic characteristics of the contingent of students and formats of educational activities. Institutionally, there is a problem of giving a different status to existing programs and teaching aids for migrant children, an urgent need to introduce and transform existing teaching methods as well as intensify professional retraining of Russian language teachers on a massive scale (Kakorina et al., 2016).

The methodological standard developed for teaching children in general education schools is focused exclusively on native speakers of the Russian language. Teachers are faced with the task of "equalizing" the level of language proficiency among native speakers and children for whom Russian is a non-native language. A teacher in a class with a multiethnic composition of students must, first of all, master the methodology of organizing a lesson based on the rhetorization of the educational process, using the possibilities of a meta-subject approach in teaching and interdisciplinary connections.

As was mentioned above, non-native speaker not only speaks another language but represents a different culture, a different worldview and attitude. Non- 
native speakers have a different cultural matrix, which complicates the process of social adaptation in the children's collective and sets the teacher the task of creating conditions for assimilation and integration into the collective of non-native learners (Usha, 2013).

An increasing number of schools in Russia are becoming multicultural every year. First of all, this is due to the intensified migration processes in the postSoviet space: people come to Russia to visit relatives or as labor migrants, since there is a serious economic crisis in their homeland and there is no opportunity to earn money (Yudina, 2006). Family migration in the host country is an important demographic resource, and Russia, as the host country, is responsible for the successful adaptation of the children of new compatriots into Russian society (Mukomel, 2014), and adaptation as a phenomenon is not just a way of human existence but also one of the mechanisms of social progress (Weber, 1990). At the same time, migrants often try to preserve their traditional way of life and pass on knowledge of both their native language and culture to their children. However, empirical data show that the identity and socio-cultural background of migrants undergoes changes in the process of adaptation to new conditions. The identity of migrants is transformed in the course of the creation of specific interaction models that allow them to maintain contacts with both the host society and the country of origin (Olimov, Olimova, 2019). The anomie of modern society presupposes the individualization of adaptation, i.e., each person has a unique adaptive trajectory corresponding to his/her normative organization (Merton, 2006). In this aspect, teachers in a multicultural school also faces the problem of preserving the cultural and linguistic identity of non-native learners (Panarin, Bochkareva, 2015). In a mixed classroom environment, a teacher must equalize the level of Russian language proficiency between non-native and native speakers, preventing the displacement of the native language matrix with the Russian language in non-native learners of Russian (Shorina, 2021).

According to E.V. Arkadyeva (2005), M.B. Bagge (2010) and I.P. Lysakova (2009), today the Russian educational system is on a threshold characterized by the danger of a generation incapable of communicative practice. The problem of teaching in a multicultural environment is that, in practice, an attempt to equalize the language level in mixed classes leads to the fact that non-native speakers really lose communicative skills in their native language; however, there is no "displacement" by the Russian language, that is, having lost the experience of communicating in their native language, they do not acquire it in the sphere of Russian. In addition, attempts to adjust the classical methods of teaching Russian to native speakers lead to a decrease in the level of development of language skills among themselves, since the learning process is deliberately slowed down by the teacher.

All these problems are superimposed on the fact that teachers, in terms of their status and official powers, should develop students' tolerance, interest in other cultures and a desire to become acquainted with the peculiarities of the traditions and languages of other peoples (Sineva, 2015).

An ethnically targeted approach to teaching the Russian language enables teachers to understand non-native learners and determine effective educational strategies suitable for representatives of a particular ethnic group; to provide assistance in solving problems of adaptation to a new socio-cultural environment; 
to determine the difficulties faced by representatives of different ethnic groups in learning the Russian language (Rumyantseva, Rubtsova, 2019).

When independently developing a methodology for teaching the Russian language in a multicultural classroom, a teacher must use an individual approach in communicating with non-native learners and their parents (Balykhina, Cherkashina, 2015). However, the lack of knowledge about culture, language and ethnic characteristics can not only hinder the establishment of ties between school and family, but also lead to interethnic and interreligious conflicts. An equally significant role is played by the psychological component: a teacher of the Russian language, being the main subject of the educational process, must direct the actions of students and determine the trajectory of mastering the subject by the class, while in a multicultural school teachers themselves are imposed a great responsibility for preserving the moral and ethical values of a multinational class and the formation of a tolerant attitude towards all participants in educational relations.

\section{Practical aspects and analysis of the experience of methodological support of classes with a multicultural component}

Let us now turn to the analysis of the pedagogical experience in developing a methodology for teaching Russian in a multicultural class. E.I. Sukhushina in her article "On the problem of teaching the Russian language to primary schoolchildren in a multiethnic class" presents statistical data and the results of implementing innovative integrative methods in Secondary School No.15 (MAEI) named after G.E. Nikolaeva in Tomsk (Sukhushina, 2015). The level of Russian language proficiency in non-native learners was determined using a diagnostic test in Russian as a foreign language for children of primary and middle school age developed by E.K. Kapelyushnik and E.A. Sherina (Kapelyushnik et al., 2015). The diagnostic test revealed a sufficient level of Russian language proficiency in 10 students (43\%), of whom two (8\%) had a high level and eight $(35 \%)$ had an average level. Insufficient language proficiency was shown by 13 students $(56 \%)$, of whom ten $(43 \%)$ had a low level and three $(13 \%)$ had a very low level. It was found that the level of language proficiency does not depend on the age of the students (Sukhushina, 2015). The diagnostic test allowed the teachers to identify the most typical and common mistakes associated primarily with the use of pronouns and verb forms in sentences. Correction and prevention of speech errors is an important task of language education of students, since errors can be caused not only by ignorance of the rules and norms, but also associated with the peculiarities of the processes of generation and perception of speech and with the specifics of constructing a linguistic worldview, especially in cases when Russian is not the student's native language and the occurrence of errors can be influenced by various linguistic and extralinguistic factors. Different errors require differentiated approaches to their prevention. Accordingly, an important condition for the effective implementation of Russian language programs in the context of bilingual and multicultural education is the development of a classification of speech errors of both multilingual and non-native learners (Tseitlin, 2000). After analyzing the tests, the teachers compiled a program of exercises for classroom training, the emphasis in which was shifted to the lexical gaps of non-native learners in the language material. It should also be noted that in order to "equalize" the level of language proficiency, the teachers of School No. 15 in Tomsk conducted addi- 
tional Russian language lessons for non-native learners, due to which it was possible to strengthen language training, improve knowledge of Russian vocabulary and grammar, as well as establish communication between the non-native and Russian-speaking children.

The vast experience and high-quality methodological base of the Moscow pedagogical community are of great scientific value for studying the problem of adaptation and integration of children of new compatriots into the Russian educational space. The tasks of methodological support of the linguistic and socio-cultural adaptation of migrant children by means of education have been successfully implemented for more than 20 years at the UNESCO Chair "International (Multicultural) Education and Integration of Migrant Children in Schools" of the Moscow Institute of Public Education (MIPE). Hundreds of teachers have undergone professional training and retraining in this chair in the specialty "Theory and Methods of Teaching Russian as a Foreign Language at School". Under the auspices of the chair, Russian as a Foreign Language groups were opened in 68 schools in Moscow. Along with that, modules of educational programs and series of teaching aids were developed, aimed at non-native children of different ages with different levels of language proficiency. Until 2018, experimental bilingual sites were successfully operating on the basis of various schools (secondary schools No. 835, 282 and many others), kindergarten schools (No. 1888) with an ethnocultural component of education. In addition, there was an experimental methodological association - "Bilingualism as a way of mastering the Russian language (Methods of teaching Russian as a second language)". It seems that the teachers have accumulated a lot of experience in working with children.

The MIPE has implemented many activities in the areas of "Harmonization of interethnic relations in the school environment" and "Training, adaptation and integration of international migrants" as part of the comprehensive action plan of the Moscow Department of Education "On measures to improve ethnocultural education". Worthy of mention is also the distant course of lectures and practical classes that existed at the Pedagogical University "September 1" as part of the advanced training program for language teachers "Theory and Methods of Teaching Russian as a Foreign Language at School" (targeted at children from migrant families) (Kakorina, Smirnova, 2016).

A number of training courses, seminars and webinars were held on the basis of the MIPE; several projects were successfully implemented, including those on training teachers and providing schools with methodological and educational literature in the disciplines of "Teaching Russian as a foreign language" and "Teaching Russian as a non-native language" at school. The international/interregional educational project included a cycle of training seminars for teachers and administrations of educational institutions - "Broadcasting the Moscow experience of adaptation of children of international migrants by means of education: "Advanced training courses for teachers of schools with teaching Russian from the countries of near and far abroad" (2014). But this work was practically stopped in 2016.

These problems are currently being being developed at the UNESCO Chair "International (Multicultural) Education and Integration of Migrants" of the Faculty of Regional Studies and Ethnocultural Education of the Institute of Social and Humanitarian Education of the Federal State Budgetary Educational Institution of 
Higher Education "Moscow Pedagogical State University" (MPSU) in cooperation with the Autonomous Non-Commercial Organization - Center for Assistance to Interethnic Education "Ethnosphere" (http://mpgu.su/integration/).

In particular, in 2020-2021, the Project "Integration of Children from Families of Foreign Ethnic Migrants by Means of Education: Methodological and Advisory Support to Schools and Kindergartens in Russian Regions" is being implemented on an ongoing basis, training webinars are held, teachers and invited methodologists frequently visit the regions of the Russian Federation, which are provided with relevant educational literature. Of course, there should be much more educational programs, manuals and methodological support structures for this area of study. We should talk about the creation (recreation) of departments, centers of scientific and methodological support for teachers of this (very specific) profile.

\section{Comparative analysis of the implementation of multicultural education programs through the example of the Republics of Sakha (Yakutia) and Tatarstan}

The state strategy for regulating interethnic relations is currently undergoing a process of updating the methodology of Soviet "nationality policy" and a transition to the development of global theoretical approaches, in which society should be focused on the values of cultural diversity and civic consolidation (Pain, Fedyunin, 2020).

The Federal Law "On the State Language of the Russian Federation" formalizes the central role of the Russian language as the state language of communication throughout the entire territory of the Russian Federation. Moreover, the law states that it is necessary to ensure "conflict-free functioning of the Russian language in conditions of bilingualism" in the territories of national republics and ethno-territorial districts. As it is known, in national regions, according to the contractual relationship between the central government and the constituent entities of the Russian Federation, it is possible to consolidate two or more state languages (Goryachev, 2015). In this case, of particular interest is the experience of teaching the Russian language in national republics, where bilingualism is widespread and there is a close interaction of two or more cultures.

For illustrative purposes, let us consider the situation that has developed in the field of studying the Russian language in the Republics of Sakha (Yakutia) and Tatarstan.

Linguistic and cultural diversity in both republics is protected by federal and regional legislation. There are special executive authorities, the main responsibility of which is to control the provision of the linguistic and cultural rights of nontitular nations. In addition, in both republics there are special federal programs aimed at preserving cultural heritage and developing language policy.

In the Republic of Sakha (Yakutia), two state languages, i.e., Russian and Yakut, are enshrined at the legislative level, and there are also five officially recognized languages of the indigenous minorities of the North, i.e., Even, Evenk, Dolgan, Chukchi and Yukagir (Chirsheva, 2013). Considering the fact that there are small indigenous ethnic groups living on the territory of the republic and the preservation of their languages and cultural identity is a priority task of state bodies, the education system has its own characteristics. 
The compact settlement of the ethnic groups makes it possible to create national schools on the territory of Yakutia, in which Russian is taught according to the educational standards as a non-native language. Since all classes have an ethnically homogeneous contingent of students, and teachers are native speakers with special training in teaching Russian, this structure fully complies with the requirements of the federal educational standard for teaching Russian as a non-native language. Learning the native language in a general educational institution is one of the necessary conditions for its preservation in the modern world. Teaching in the native language is recognized by the world community as one of the main means of improving the quality of education (Borisova, 2012).

The interrelated teaching of Russian and native languages is fundamentally important in the context of active bilingualism (Balykhina, 2007). Among teachers and researchers of the educational system of Yakutia, the prevailing opinion is that learning native, Russian and foreign languages students become ready to live in a multilingual world, while taking care of their own culture, as well as know languages and respect cultures of other peoples (Nikiforova et al., 2016). Thus, on the territory of the Republic of Sakha (Yakutia) there are no problems with the formation of a modern multicultural school, but there is a demand for the formation of new educational and methodological complexes and materials for teaching Russian as a non-native language. On the territory of Yakutia, as noted above, there are a large number of small ethnic groups; however, educational, methodological and didactic complexes have been developed only for the most widespread ethnic groups. The list of federal schoolbooks includes only textbooks and manuals for teaching Russian as a non-native language for seven ethnic groups, the rest of the small nationalities are trained using existing teaching materials. In these conditions, there is a need for the preparation and publication of new textbooks on the Russian language with their subsequent inclusion in the federal list. The teachers and scientists of the Sakha Republic consider it expedient to publish educational and methodological complexes for national schools in such language groups as Turkic, Finno-Ugric, Abkhaz-Adyghe and Mongolian.

The situation with language education on the territory of the Republic of Tatarstan differs significantly from that of Yakutia. Officially, until 2017, the Russian language in this republic was taught according to two standards, i.e., teaching Russian for native speakers and teaching Russian as a non-native language for national schools, where instruction is in Tatar and Russian is studied as a subject. In fact, each school implemented the standard of teaching Russian as a non-native language, the number of hours of the Tatar language per week reached six. Despite the organizational status, all the schools implemented one educational program. The main difference was only in the fact that in Tatar lyceums and gymnasiums, instruction was conducted entirely in the Tatar language, whereas in other educational institutions it was in Russian. However, formally, there was no difference between the structure and workload. In 2017, the authorities of the republic made adjustments to the curricula and officially assigned the status of a national component to the Tatar language, which became mandatory for study only in national schools, i.e., Tatar lyceums and gymnasiums. At the same time, it was recommended to earn the Tatar language as an optional element, i.e., a subject chosen at the written request of the students' representatives: parents or guardians. 
We cannot talk about the presence of multicultural schools in Tatarstan, since students, i.e., representatives of the Tatar ethnic group, know Russian to the extent necessary to master the school curriculum and, therefore, they do not need to undergo special language training and change the program in order to "balance" language skills (Mukhametshina, 2014). According to the analysis of statistical data, $99.8 \%$ of Tatars living in urban areas on the territory of the Republic of Tatarstan speak Russian at a level sufficient for communication (Luchsheva, 2014).

However, difficulties with the curricula still exist. In practice, in each school of the republic, the majority of Tatars, as well as some Russians, choose the Tatar language proposed to them as an optional additional lesson; this subject is fixed in the curriculum, and a fairly large number of hours are allocated to it. However, students who have given up learning the Tatar language cannot study Russian at the same time, since this would create an inequality in mastering the Russian language program between those who attend Tatar language lessons and those who have withdrawn from them. School administrators also cannot let children who do not want to learn the Tatar language go home, because the hours of the Tatar language are often integrated into the timetable and are not the first or last lesson. Moreover, such a situation could create some inequality in the number of hours of study and time of being at school and lead to a conflict between students. Taking into account the current situation, schools implement two learning scenarios.

Thus, we can conclude that the Russian language is taught in the national subjects of the Russian Federation mainly according to the standard of teaching Russian as a non-native language. At the same time, the linguistic situations in the republics are completely different. If in Yakutia the majority of small ethnic groups really have a need to study Russian as a foreign language, and their level of Russian language proficiency does not allow successful communication and requires special adjustment and training through special programs, in the Republic of Tatarstan, the situation is quite different, i.e., the level of Russian language proficiency of all the ethnic groups living on the territory of this republic is extremely high.

\section{Conclusion}

The Russian Federation is a multinational state; many large and small ethnic groups live on the territory of our country. The Russian language plays a vital role in the development of communication and interaction between different peoples. Performing an integrating function, it is a guide to world culture, it preserves and reproduces the memory of our common multinational ancestors, the history of the multiethnic state (Dmitriev, 1999). The Russian state is an active political actor in the international arena and experiences all the effects of world socio-economic and political trends.

Today, in the context of globalization, labor migration has become widespread. The economic crisis in the post-Soviet space is responsible for the increased flow of migrants in recent years (Bauman, 2004). This tendency leads to the increasing spread of a new phenomenon, i.e., the emergence of multicultural Russian schools.

It should be noted that, in fact, all schools in the Russian Federation are, on the one hand, Russian national (according to the educational standard) and, on the other hand, multiethnic (taking into account students of different nationalities). In such schools, students from different ethnic groups study together. Thus, we can distinguish the following types of multiethnic schools: 
1) with a predominantly non-Russian-speaking students (Republic of Sakha (Yakutia));

2) with an approximately equal ratio of Russian-speaking and non-Russianspeaking students (Republic of Tatarstan);

3) having $20-30 \%$ of non-Russian-speaking students (Moscow, St. Petersburg, Tomsk, etc.).

We draw your attention to the fact that the concept of "multiethnic school" in connection with the qualitative change in the non-Russian school contingent passes into the concept of "multicultural school", which describes the school communicative space according to the principle of belonging to different cultures (rather than to a particular nationality) and the sign of "native speakers of Russian/native speakers of a foreign language".

In a modern school, where the multiethnicity of the contingent is characterized by multilingualism and multiculturalism, the dialogue of cultures should be built both in class and in extracurricular activities.

The main problem that such an innovative type of school is facing today is updating the mechanisms for implementing the Russian language teaching program in classes, where students have different levels of Russian language proficiency.

It seems to us that the solution to the accumulated problems associated with the current growth in the number of multicultural schools lies in the creation of an innovative integrated model of teaching the Russian language in a multicultural environment, taking into account the existing methods and practices.

\section{References}

Ahiezer, A. (2013). Migratsiya v rossiiskoi istorii. Migratsiya v Rossii 2000-2012: (pp. 581-586). Moscow: Speckniga Publ. (In Russ.)

Anderson, L.M., \& Stillman, J.A. (2013). Student teaching's contribution to preservice teacher development: A review of research focused on the preparation of teachers for urban and high-needs contexts. Review of Educational Research, 83(1), 3-69. https://doi.org/10.3102/0034654312468619

Antrop-González, R., Vélez, W., \& Garrett, T. (2008). Examining familial-based academic success factors in urban high school students: The case of Puerto Rican female high achievers. Marriage \& Family Review, 43(1-2), 140-163. https://doi.org/10.1080/01494920802013003

Arkadeva, E.V. (2005). Zhivaya metodika prepodavaniya russkogo yazyka kak inostrannogo: Uchebnoe posobie dlya vuzov. Moscow: Drofa Publ. (In Russ.)

Azimov, E.G., \& Shukin, A.N. (2009). Novyi slovar' metodicheskikh terminov i ponyatii (teoriya i praktika obucheniya yazykam). Moscow: IKAR Publ. (In Russ.)

Bagge, M.B., Belova, M.G., \& Ilakavichus, M.R. (2010). Russkii yazyk v polietnicheskikh klassakh. Saint Petersburg: SPB APPO Publ. (In Russ.)

Balykhina, T.M. (2007). Metodika prepodavaniya russkogo yazyka kak nerodnogo (novogo). Moscow: RUDN University Publ. (In Russ.)

Balykhina, T.M., \& Cherkashina, T.T. (2015). Multicultural format of foreign language education. Polylinguality and Transcultural Practices, (1), 42-49. (In Russ.)

Banks, J.A. (1993). Multicultural education: Historical development, dimensions, and practice. Review of Research in Education, 19(1), 3-49. https://doi.org/10.2307/1167339

Bauman, Z. (2004). Globalizatsiya. Posledstviya dlya cheloveka i obshchestva. Moscow: Ves` mir Publ. (In Russ.)

Bek, U. (2001). Chto takoe globalizatsiya? Moscow: Progress-Traditsiya Publ. (In Russ.)

Borisova, L.P. (2012). Strategy of the language education in the Republic of Sakha (Yakutia). European Social Science Journal, 3(19), 273-276. (In Russ.) 
Borisova, L.P., \& Shadrina, S.N. (2012). Role of Russian language in the development of national identity. Theory and Practice of Social Development. Scientific Journal, (12), 221-224. (In Russ.)

Bunyan, T. (1991) Towards an authoritarian European state. Race and Class, 32(3), 19-27. https://doi.org/10.1177/030639689103200304

Bystrova, E.A. (2002). Dialog kul'tur na urokakh russkogo yazyka: Posobie po razvitiyu rechi uchashchikhsya 7-9 klassov obshcheobrazovatel'nykh shkol. Saint Petersburg: Prosveshchenie Publ. (In Russ.)

Chirsheva, G.N. (2013). Monoethnic childhood bilingualism. Philological Class, 2(32), 46-49. (In Russ.)

Darder, A. (2012). Culture and power in the classroom: A critical foundation for the education of bicultural students. Boulder, CO: Paradigm Press. https://doi.org/10.4324/9781315635347

Dmitriev, G.D. (1999). Mnogokul turnoe obrazovanie. Moscow: Narodnoe obrazovanie Publ. (In Russ.)

Faas, D. (2011) The nation, Europe and migration: A comparison of geography, history and citizenship education curricula in Greece, Germany and England. Journal of Curriculum Studies, 43(4), 471-492. https://doi.org/10.1080/00220272.2011.584560

Garreta Bochaca, J. (2006) Ethnic minorities and the Spanish and Catalan educational systems: From exclusion to intercultural education. International Journal of Intercultural Relations, 30(2), 261-279. https://doi.org/10.1016/j.ijintrel.2005.11.006

Gay, G. (2010). Culturally responsive teaching: Theory, research, and practice (2nd ed.). New York, NY: Teachers College Press.

Goryachev Y.A. (2015). Russian and international regulatory framework to improve teachers' professional competence in inter-ethnic relations as part of the educational policy of the national policy strategy of the Russian Federation till 2025 (analytical overview). Ethnodialogies, (2), 21-50. (In Russ.)

Heckmann, F. (2008). Education and migration. Strategies for integrating migrant children in European schools and societies. A synthesis of research findings for policymakers. NESSE.

Heidegger, M. (2002). Bytie i vremya. Saint Petersburg: Nauka Publ. (In Russ.)

Jackson, R., Miedema, S., Weisse, W., \& Willaime, J.-P. (Eds) (2007). Religion and education in Europe: Developments, contexts and debates. Munster: Waxmann. https://doi.org/10.1111/j.1467-8527.2008.00414_4.x

Kakorina, E.V., \& Smirnova, N.L. (2016). The readiness of migrants' children to schooling in Russian: The arrangement of a testing lesson and the analysis of results. Philological Class, (2), 40-48. (In Russ.) https://doi.org/10.26710/fk16-02-07

Kakorina, E.V., Kostyleva, L.V., Krivoruchko, T.V., Sineva, O.V., \& Shorina, T.A. (2016). Russkii Yazyk v Raznourovnevom Polikul'turnom Klasse: Tekhnologii Yazykovoi Adaptatsii. Moscow: GAOU VO MOO Publ. (In Russ.)

Kalenkova, O.N., Omelchenko, E.A., Feoktistova, T.L., \& Shorina, T.A. (2012). Uchimsya Zhit' v Rossii: Uchebno-Metodicheskij Komplekt. Posobie po Social'no-Kul'turnoj Adaptacii. Moscow: GAOU VPO MIOO - Etnosfera Publ. (In Russ.)

Kapelyushnik, E.V., Mukhacheva, A.M., Ponomareva, L.A., \& Sherina, E.A. (2005). Mezhdu strok. Prodvinutyi etap. Tomsk: TPU Publ. (In Russ.)

Khamraeva, E.A. (2017). Teoriya i metodika obucheniya detei-bilingvov russkomu yazyku. Saint Petersburg: RGPU imeni A.I. Gertsena Publ. (In Russ.)

Khamraeva, E.A. (2020). Kompleksnaya diagnostika detei, naslednykh nositelei russkogo yazyka, v tselyakh preodoleniya yazykovoi attritsii. Yazyk $i$ Myshlenie: Psikhologicheskie i Lingvisticheskie Aspekty: Conference Proceedings (pp. 119-122). Pokrov: Moskovskii pedagogicheskii gosudarstvennyi universitet Publ. (In Russ.)

Ladson-Billings, G. (2014). Culturally relevant pedagogy 2.0: Aka the remix. Harvard Educational Review, 84(1), 74-84. https://doi.org/10.17763/haer.84.1.p2rj131485484751

Luchsheva, L.V. (2014). Functions and status of the Russian language in the Republic of Tatarstan. Bulletin of Economics, Law and Sociology, (1), 152-155. (In Russ.)

Lysakova, I.P. (2009). Russkii yazyk kak nerodnoi: Sotrudnichestvo nauki i praktiki v shkolakh Sankt-Peterburga. Mir Russkogo Slova, (4), 76-80. (In Russ.) 
Markosyan, A.S. (2004). Ocherk teorii ovladeniya vtorym yazykom. Moscow: Psikhologiya Publ. (In Russ.)

Merton, R.K. (2006). Sotsial'naya teoriya i sotsial'naya struktura. Moscow: AST Publ., Khranitel' Publ. (In Russ.)

Mukhametshina, R.F. (2014). Dialog kul'tur v literaturnom obrazovanii kak uslovie mezhetnicheskogo soglasiya i vzaimodeistviya. Pozitivnyi Opyt Regulirovaniya Etnosotsial'nykh $i$ Etnokul'turnykh Protsessov v Regionakh Rossiiskoi Federatsii: Conference Proceedings (pp. 451-454). Kazan': Institut istorii imeni Shigabutdina Mardzhani Akademii nauk Respubliki Tatarstan Publ. (In Russ.)

Mukomel, V.I (2014). Migranty, migrantofobii i migratsionnaya politika. Moscow: Tsentral'nyi dom advokata Publ., Moskovskoe byuro po pravam cheloveka Publ., Akademia Publ. (In Russ.)

Nikiforova, E.P., Borisova, L.P., \& Shadrina, S.N. (2016). Problems of teaching Russian language and literature in the multicultural environment. Historical and Social-Educational Idea, 8(4/1), 148-155. (In Russ.)

Olimov, M.A., \& Olimova, S.K. (2019). Transformation of Identity in migration: Ethnicity and religion (on the example of Tajik labour migration in Russia). Bulletin of Tomsk State University. History, (59), 158-166. (In Russ.) https://doi.org/10.17223/19988613/59/21

Pain, E.A., \& Fedyunin, S.Y. (2020). The policy of interculturalism and the possibilities of its application in Russia. Polis. Political studies, (1), 114-134. (In Russ.) https://doi.org/10.17976/jpps/2020.01.09

Panarin, S.A., \& Bochkareva, I.B. (2015). Vostok na Vostoke, Vostok na Zapade i Vostok v Rossii: Migratsiya - adaptatsiya - identichnost'. Vostok. Afro-Aziatskie Obshhestva: Istoriya i Sovremennost, (3), 160-166. (In Russ.)

Poletaev, D.V., \& Zaionchkovskaya Zh.A. (2019). Analiz mekhanizmov, problem i praktik adaptatsii i integratsii detei, ne imeyushchikh grazhdanstva RF i prebyvayushchikh $\mathrm{v}$ Moskve. Obshchestvo. Doverie. Riski: Doverie k Migratsionnym Protsessam. Riski Novogo Obshchestva: Conference Proceedings (pp. 315-325.). Moscow: The State University of Management Publ. (In Russ.)

Protasova E.Yu., \& Rodina, N.M. (1999). Stanovlenie i funkcionirovanie dvuyazychiya. Materialy po issledovaniyu bilingvizma. Moscow: Moskovskii komitet obrazovaniya Publ. (In Russ.)

Protasova, E.Y., \& Rodina, N.M. (2005). Zarubezhnye dvuyazychnye programmy obucheniya. Russkii Yazyk vne Rossii: Conference Proceedings (pp. 100-111.). Moscow: Etnosfera Publ. (In Russ.)

Protasova, E.Y., \& Rodina, N.M. (2010). Metodika obucheniya doshkol'nikov inostrannomu yazyku. Moscow: Vlados Publ. (In Russ.)

Pugachev, I.A. (2011). Etnoorientirovannaya metodika v polikulturnom prepodavanii russkogo yazyka inostrancam. Moscow: RUDN University Publ. (In Russ.)

Rumyantseva, N.M., \& Rubtsova, D.N. (2019). Ethno-oriented training as an important component of methodology of teaching Russian as a foreign language. Izvestia of the Southern Federal University. Philological Sciences, (1), 196-207. (In Russ.) https://doi.org/10.23683/1995-0640-2019-1-196-207

Shorina, T.A. (2021) Poli-cultural education today: The experience of Moscow and Saint Petersburg. Ethnodialogies, (1), 91-107. (In Russ.)

Sineva, O.V. (2015). Yazyk sem'i i problemy obucheniya v obrazovatel'nom uchrezhdenii v usloviyakh bilingvizma. Russkii Yazyk bez Granits: Conference Proceedings (pp. 88-96). Moscow: Etnosfera Publ. (In Russ.)

Stolbova, Ja.E. (2014). Problems of teaching the Russian Language in multi-ethnic classes. Yaroslavl Pedagogical Bulletin, 2(1), 94-97. (In Russ.)

Sukhushina, E.I. (2015). On the problem of teaching Russian to younger schoolchildren in polyethnic class. Pedagogical Review, 3(9), 92-100. (In Russ.)

Toshchenko, Zh.T. (2015). Sociology of life as a theoretical conception. Sociological Research, (1), 106-116. (In Russ.)

Tseitlin S.N. (2000). Yazyk i rebenok. Lingvistika detskoi rechi. Moscow: Vlados Publ. (In Russ.)

Usha, T.Y. (2012a). National Russian school - the multiethnic and multicultural one. Izvestia: Herzen University Journal of Humanities \& Sciences, (148), 125-133. (In Russ.) 
Usha, T.Y. (2012b). Language identification of foreign language students. IKBFU's Vestnik: Philology, Pedagogy, and Psychology, (2), 100-105. (In Russ.)

Usha, T.Y. (2013). The Russian language in a multicultural school as a methodological problem. Bulletin of Immanuel Kant Baltic Federal University, (11), 28-33. (In Russ.)

Weber, M. (1990). O nekotorykh kategoriyakh ponimayushchei sotsiologii. Moscow: Progress Publ. (In Russ.)

Yudina, T.N. (2006). Sotsiologiya migratsii. Moscow: Akademicheskii Proekt Publ. (In Russ.)

\title{
Article history:
}

Received 5 August 2021

Revised 7 October 2021

Accepted 12 October 2021

\section{For citation:}

Kytina, N.I., \& Khamraeva, E.A. (2021). The current state of the teaching the Russian language in the multicultural Russian school. RUDN Journal of Psychology and Pedagogics, 18(4), 785-800. http://dx.doi.org/10.22363/2313-1683-2021-18-4-785-800

\section{Bio notes:}

Natalia I. Kytina, Deputy Director for Academic and Methodological Work, Municipal Autonomous Educational Institution "Domodedovskaya Secondary School No. 1". ORCID: 0000-0002-9291-8091, eLIBRARY SPIN-code: 1335-5800, Research AuthorID: 1116400, ScopusID: 57211459397. E-mail: kytinanatalia@mail.ru

Elizaveta A. Khamraeva, Doctor of Pedagogy, Professor, is Head of the Department of Russian as a Foreign Pre-University Education, Preparatory Faculty for Foreign Citizens, Institute of Philology, Moscow Pedagogical State University; Director of the Center for Bilingual and Multicultural Education, Herzen Russian State Pedagogical University. ORCID: 0000-0002-8551-5462, eLIBRARY SPIN-code: 7025-3780, Research AuthorID: 776178. E-mail: elizaveta.hamraeva@gmail.com

\section{Актуальные проблемы преподавания русского языка в поликультурной российской школе}

\author{
Н.И. Кытина ${ }^{1} \otimes$, Е.А. Хамраева ${ }^{2,3}$ (D) \\ ${ }^{1}$ Домодедовская средняя общеобразовательная школа № 12, \\ Российская Федераџия, 142030, Павловское, ул. Колхозная, д. 17 \\ ${ }^{2}$ Московский педагогический государственный университет, \\ Российская Федераџия, 119991, Москва, ул. Малая Пироговская, д. 1, стр. 1 \\ ${ }^{3}$ Российский государственный педагогический университет имени А.И. Герцена, \\ Российская Федераџия, 191186, Санкт-Петербург, набережная реки Мойки, д. 48 \\ 凶ytinanatalia@mail.ru
}

Аннотация. Доминирующей тенденцией развития современного постиндустриального общества, как известно, является глобализация, но в настоящее время можно говорить уже о «глокализации» как двунаправленном процессе интеграции и локализа- 
ции, взаимодополняющем диалектическом развитии человечества. Этот процесс подразумевает объединение всех сфер жизни социума в едином глобальном пространстве и обособление отдельных регионов и этнических групп в качестве защитной реакция для сохранения своей уникальности и самобытности. Описанные социальные тенденции становятся определяющими для развития системы образования как основного социального института. Миграционные процессы и связанные с ними проблемы интеграции мигрантов в новый социум, вопросы сохранения национального языка и культуры, поиск идентичности - все эти явления обуславливают необходимость инновационных методологических решений, которые должны быть реализованы в контексте изучения русского языка на уроках в поликультурной российской школе. Рассмотрены актуальные проблемы, связанные с реализацией программы обучения русскому языку в поликультурной среде. Предложено концептуальное определение поликультурной школы. Проанализирован педагогический опыт отдельных образовательных учреждений, разрабатывающих авторские методики обучения в поликультурной среде. Выявлены социальноадаптивный, культурологический, психологический и лингвистический аспекты проблематики преподавания русского языка в поликультурной школе. Отмечено усиление психоэмоциональной нагрузки педагогов, работающих в полиэтнических классах. Проанализирована ситуация с преподаванием русского языка в полиэтнических регионах России на примере Республик Саха (Якутия) и Татарстан. Отмечено, что для регионов РФ методологически неверно использовать термин «поликультурная школа», так как в национальных субъектах РФ существует особый тип национальных школ, а также реализуется программа изучения русского языка как неродного.

Ключевые слова: педагогика, русский язык, поликультурная школа, мультикультурализм, социальная адаптация, инофоны, билингвизм, русский язык как неродной, русский язык как иностранный, полиэтническая среда

\section{История статьи:}

Поступила в редакцию: 8 августа 2021 г.

Принята к печати: 12 октября 2021 г.

\section{Для цитирования:}

Kytina N.I., Khamraeva E.A. The current state of the teaching the Russian Language in the multicultural Russian school // Вестник Российского университета дружбы народов. Серия: Психология и педагогика. 2021. Т. 18. № 4. С. 785-800. http://dx.doi.org/10.22363/23131683-2021-18-4-785-800

\section{Сведения об авторах:}

Кытина Наталья Ивановна, заместитель директора по учебно-методической работе, Муниципальное автономное общеобразовательное учреждение «Домодедовская средняя общеобразовательная школа № 12». ORCID: 0000-0002-9291-8091, eLIBRARY SPINкод: 1335-5800, Research AuthorID: 1116400, ScopusID Author ID57211459397. E-mail: kytinanatalia@mail.ru

Хамраева Елизавета Александровна, доктор педагогических наук, профессор, заведующая кафедрой русского языка как иностранного довузовского обучения, подготовительный факультет для иностранных граждан, Институт филологии, Московский педагогический государственный университет; директор Центра билингвального и поликультурного образования, Российский государственный педагогический университет имени А.И. Герцена. ORCID: 0000-0002-8551-5462, eLIBRARY SPIN-код: 7025-3780, Research AuthorID: 776178. E-mail: elizaveta.hamraeva@gmail.com 